\title{
PALAEOGRAPHIC EVOLUTION OF PINDOS BASIN DURING PALEOGENE USING CALCAREOUS NANNOFOSSILS
}

\author{
Ananiadis G. ${ }^{1}$, Vakalas I. ${ }^{1}$ Zelilidis A. ${ }^{1}$, and Stoykova K. ${ }^{2}$ \\ 1 Department of Geology, University of Patras, 26500, Patras, Gananiad@upatrtas.gr \\ IVakalas@upatras.gr, A.Zelilidis@upatras.gr \\ ${ }^{2}$ Department of Paleontology and Stratigraphy, Geological Institute of Bulgary, Academy of \\ Sciences, Stoykova@router.geology.bas.bg
}

\section{ABSTRACT}

A different basin evolution is suggested between the northern and southern parts of the Pindos basin, based on biostratigraphic dating results. Characteristic nannofossils showed that flysch sedimentation in the whole basin started in the Paleocene and generally finished during the Eocene, with the exception of the Konitsa and Milia areas where sedimentation lasted until Early Oligocene. Although, basin depth increased southwards, Kastaniotikos and Sperchios faults affected the geometry of Pindos basin, creating ridges and troughs within the basin. Due to this segmentation of the basin, the continuity of the sedimentation in the northern part of the study area until Oligocene is suggested. Calcareous nannofossils recovered from this northern part indicate a Paleocene NP5 to early Cligocene (NP20-21) age. On the other hand, in the southern part, sedimentation of flysch was lasted until middle Eocene. According this model, sedimentation in the southern part, stopped during the middle Eocene, was followed by subaerial exposure and the migration of clastic sedimentation to the western part of Pindos zones (Pindos foreland basin of lonian zone). At this time, in the northern part, a small-restricted basin was continuously active as a piggyback basin from upper Eocene to lower Oligocene and shallow deposits (slope and submarine canyon deposits, delta fan deposits) accumulated.

\section{INTRODUCTION}

The early Tertiary renewed crustal compression initiated eastward subduction of the remnant Pindos Ocean Basin, where submarine fans accumulated during Paleogene giving rise to Pindos flysch. Closure of the remnant Pindos Ocean initiated at Early Tertiary (Robertson et al., 1991) with the eastward subduction of the Apulia continental crust beneath the continental crust of Pelagonian plate. The closing is recorded by the transition from shallow carbonate to deep clastic sedimentation. According to Fleury (1980), clastic sedimentation started at Early Paleocene.

\section{METHODOLOGY}

Samples were collected from eight cross-sections through out Pindos flysch deposits in order to determine the duration of clastic sedimentation. The cross-sections from north to south where: A-A' (road from Konitsa to Eptachori) and B-B' (road from Elefthero to Paleoseli) situated in Konitsa area, C-C' (road from Votonosi to Metsovo), D-D' (Chrisovitsa) and E-E' (road from Metsovo to Milia) situated in Metsovo area, Z-Z' (road from Kastanea to Doliana) situated in Kastania area, I-I' (road from Fournas to Loutra) situated in Karpenisi area, and K-K' (road from Nafpaktos to Lidoriki) situated in Nafpaktos area. Thus 195 muddy samples where dated using calcareous nannofossils according Martini (1971) biozones (Fig.1). 


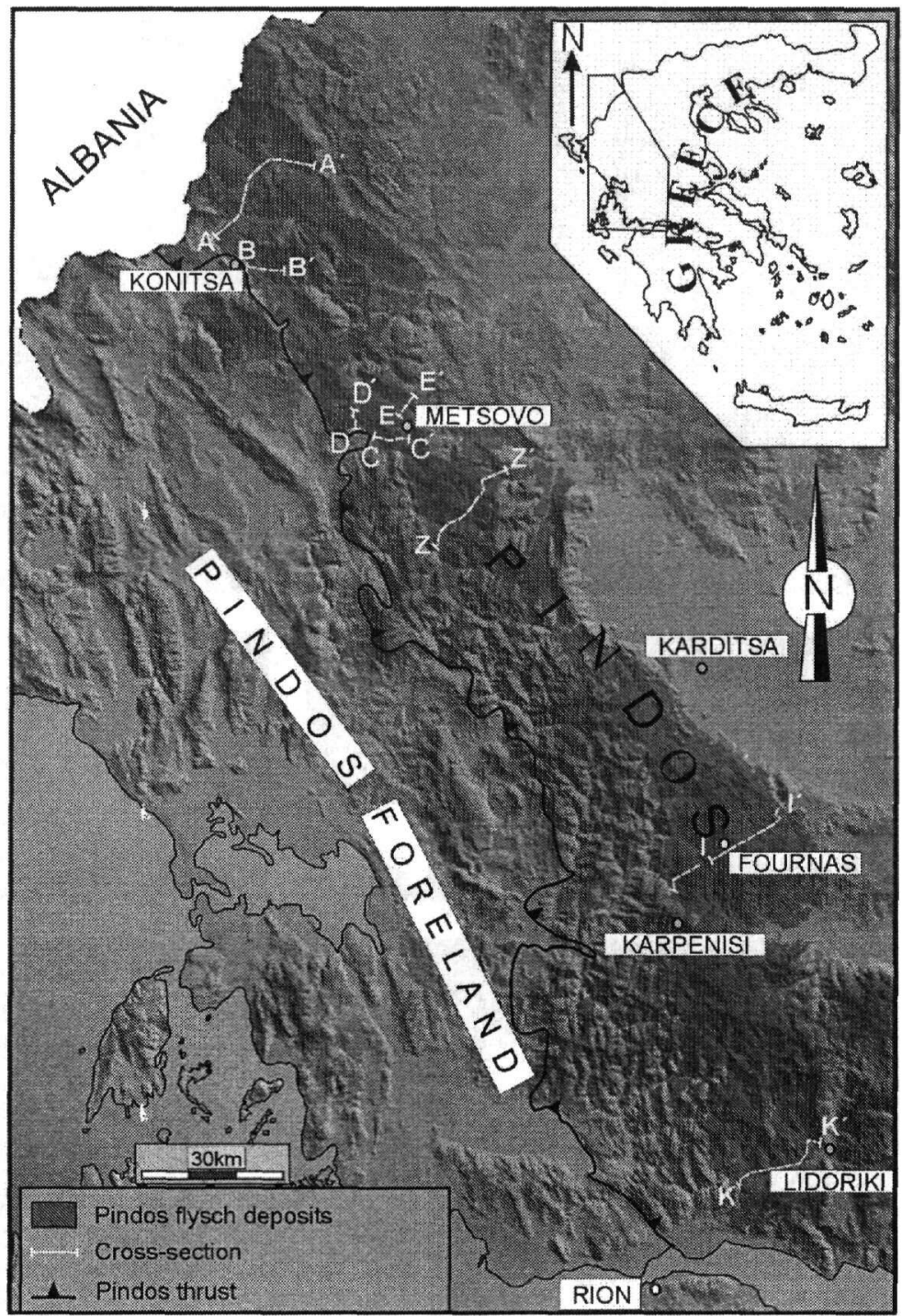

Figure 1. Geological map of the studied area showing the selected cross-sections for stratigraphic analysis.

\section{STRATIGRAPHY}

\subsection{Age determinations}

In the northern part, dating results (plate 1) from cross-section $A-A^{\prime}$ ranged from Paleocene (NP9) to earliest Oligocene (NP20-21), B-B' ranged from middle Eocene (NP16) to earliest Oligocene (NP20-21). Age of Sediments from cross-sections C-C' (Fig. 2) and D-D' ranged from middle Eocene (NP16-17) to middle-late Eocene (NP16-20), while sediments of cross-section E-E' ranged from middle Eocene (NP16-17) to earliest Oligocene (NP20-21). In the southern part, dating results (plate 2) from cross-section Z-Z' ranged from Paleocene (NP5) to Early Eocene (NP11-12), from cross-section I-I' ranged from Late Paleocene (NP5-9) to middle Eocene (NP16-17) and finally, sediments from cross-section K-K' dated from late Paleocene (NP5-8) to early Eocene (NP11-14). So, it seams that flysch sedimentation began in the Paleocene and finished during the Eocene, with the exception of Milia and Konitsa areas where sedimentation lasted until Early Oligocene. 


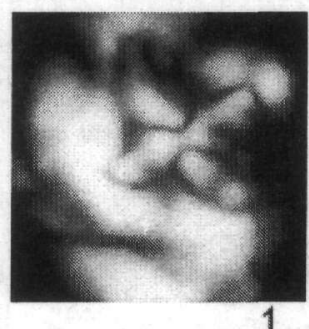

1

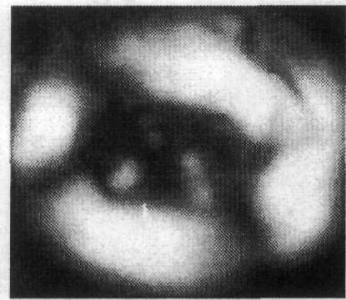

4

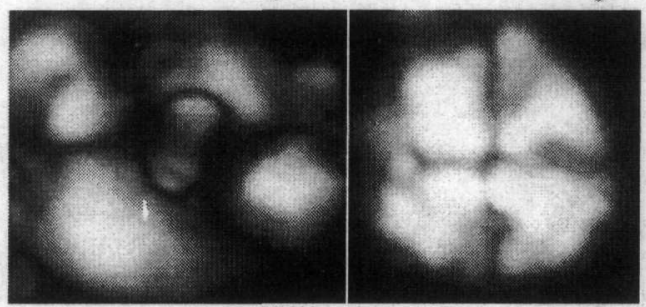

7

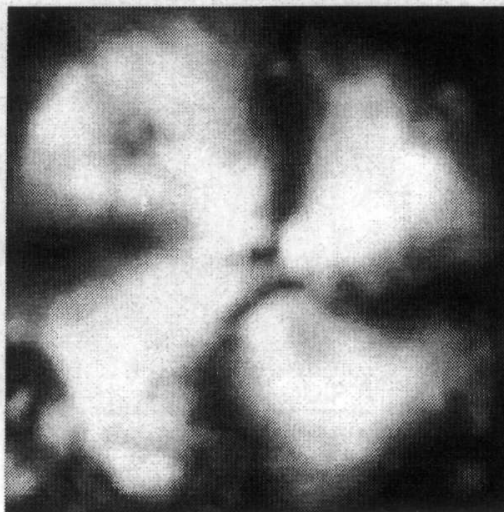

10

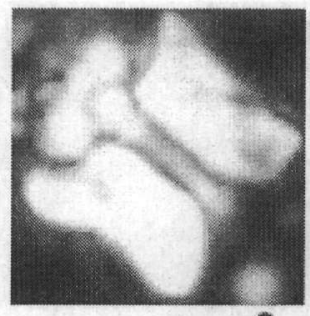

2

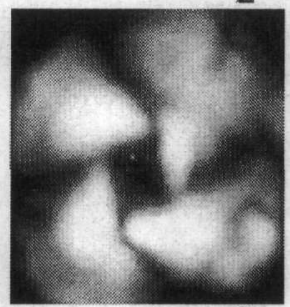

5

8
$10 \mu \mathrm{m}$

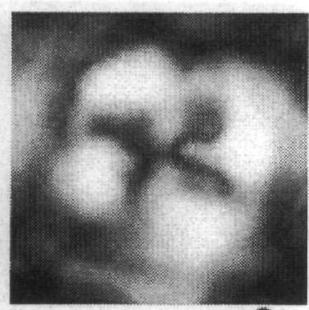

3

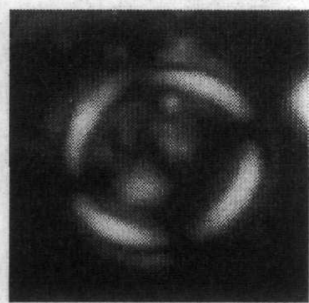

6

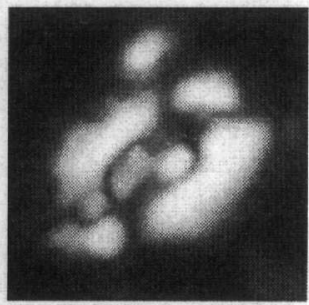

9

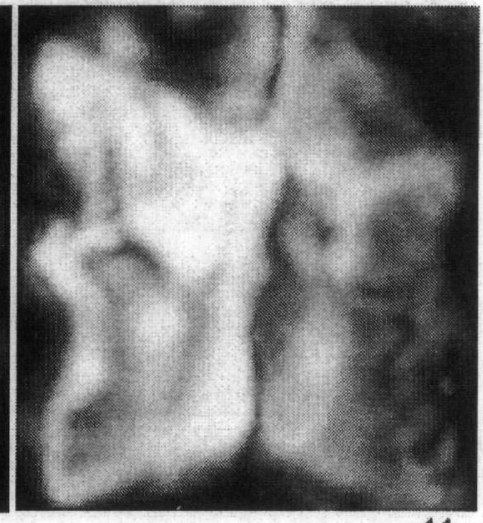

Plate I: 1. Cruciplacolithus tenuis. Section Konitsa KON40, Upper Paleocene, NP8-9, 2. Sphenolithus anarrhopus. Section Konitsa KON40, Upper Paleocene, NP8-9, 3. Prinsius bisulcus. Section Konitsa AA'5, Paleocene, NP5-8, 4. Fasciculithus tympaniformis. Section LL'245, Upper Paleocene, NP7-8, 5. Toweius gammation. Section Metsovo DD'27, Lower Eocene, NP12-14, 6. Sphenolithus editus. Section CC'231, Lower Eocene, NP12-14, 7. Chiasmolithus grandis. Section Metsovo Mets2, Middle Eocene, NP16-17, 8. Ericsonia formosa. Section Metsovo EE'152, Middle Eocene, NP16-17, 9. Cribrocentrum reticulatum. Section Metsovo EE'157, Middle-Upper Eocene, NP16-18, 10. Heliolithus kleinpellii. Section Konitsa KON40, Upper Paleocene, NP8-9, 11. Reticulofenestra umbilica. Section Metsovo EE'154, Middle-Upper Eocene, NP16-18 

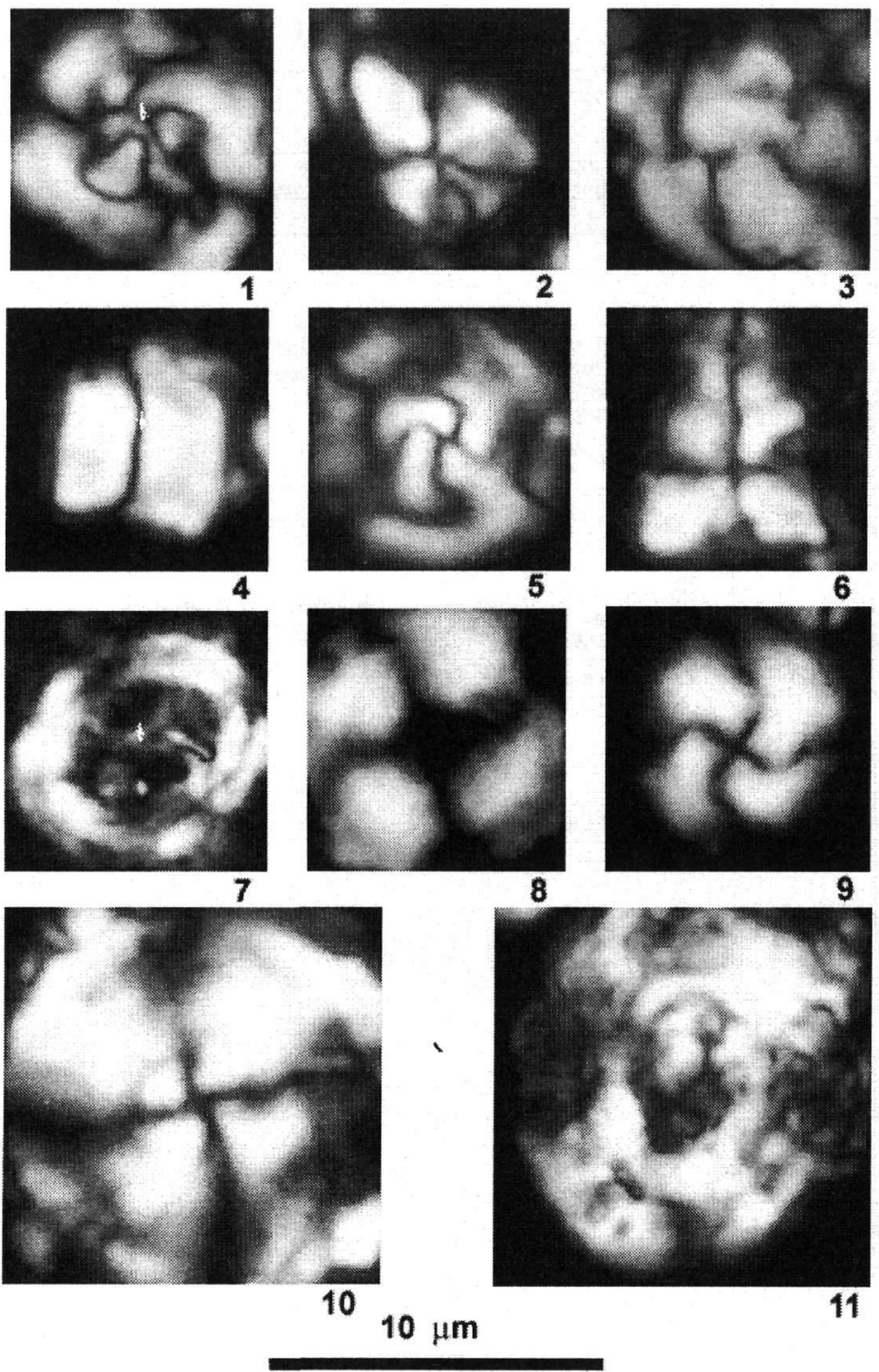

Plate II: 1. Cruciplacolithus frequens. Section LL'242, Paleocene NP2-7, 2. Fasciculithus billii. Section HH'422, Middle Paleocene NP5, 3. Toweius eminens. Section HH'102, Upper Paleocene, NP8-9, 4. Chiasmolithus consuetus. Section II'330, Lower-Middle Eocene NP12-16, 5. Reticulofenestra dictyoda. Section II'330, LowerMiddle Eocene NP12-16, 6. Geminilithella rotula. Section II'335, Middle Eocene NP16-17, 7. Helicosphaera seminulum. Section II'330, Lower-Middle Eocene NP12-16, 8. Sphenolithus compactus. Section II'117, Middle Eocene NP16-17, 9. Helicosphaera bramlettei. Section II'335, Middle Eocene NP16-17, 10. Heliolithus kleinpellii. Section HH'102, Upper Paleocene, NP8-9, 11. Fasciculithus tonii. Section HH'102, Upper Paleocene, NP8-9.

\subsection{Stratigraphic application}

According to the detail age determination and in relation to sedimentological and tectonic data studied cross-sections (e.g. representative cross-section C-C': Fig. 2) broken into sequences (e.g. 
cross-section C-C': Fig. 3), showing the real stratigraphic thickness and the influence of tectonic activity. After this a biostratigraphic correlation was drawn in order to show basin evolution from north to south (Fig. 4).

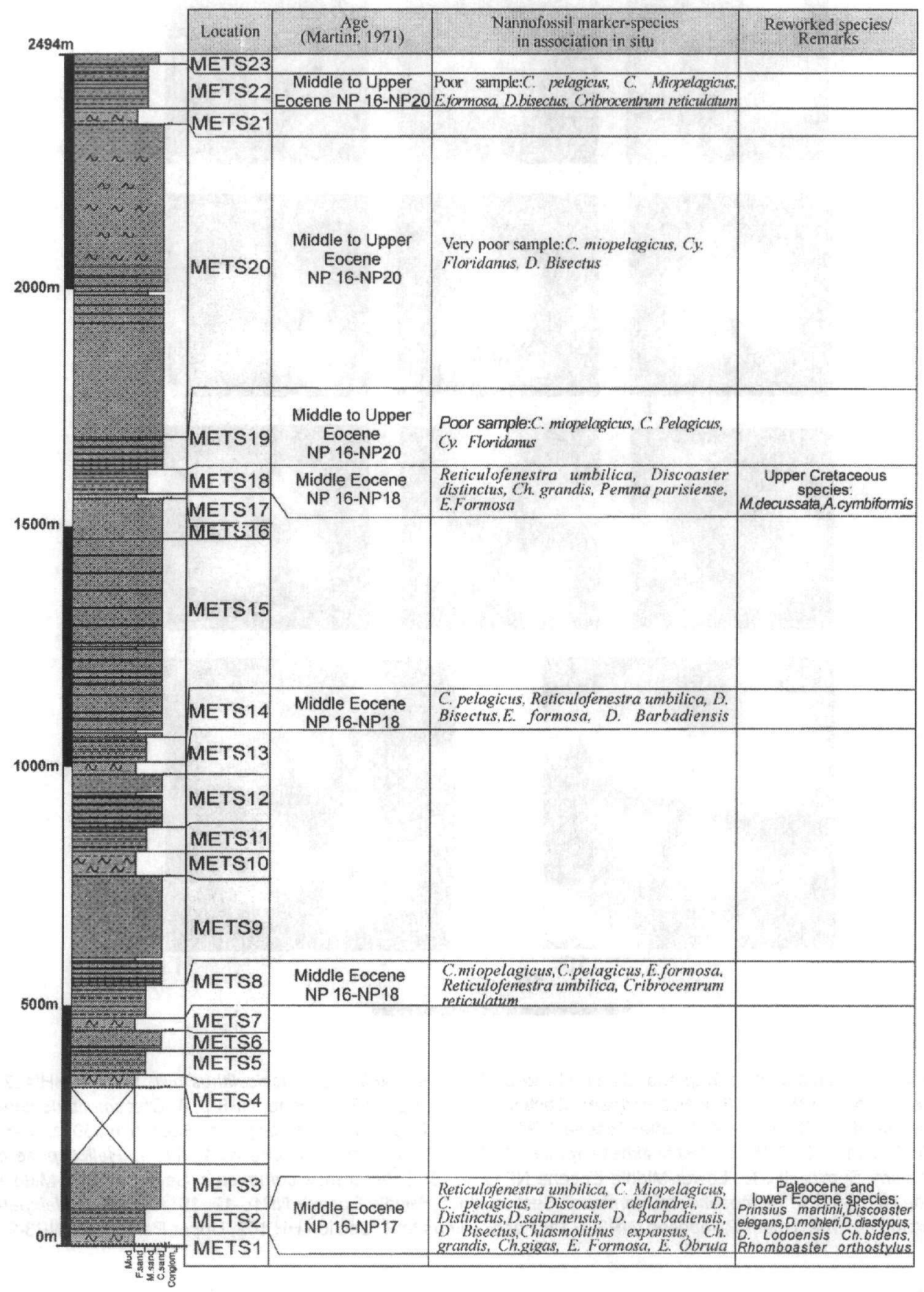

Figure 2. Representative lithostratigraphic column of cross-section $\mathrm{C}^{-} \mathrm{C}^{\prime}$, showing the total outcropping thickness from $C$ to $C^{\prime}$, and before segmented this into sequences. 


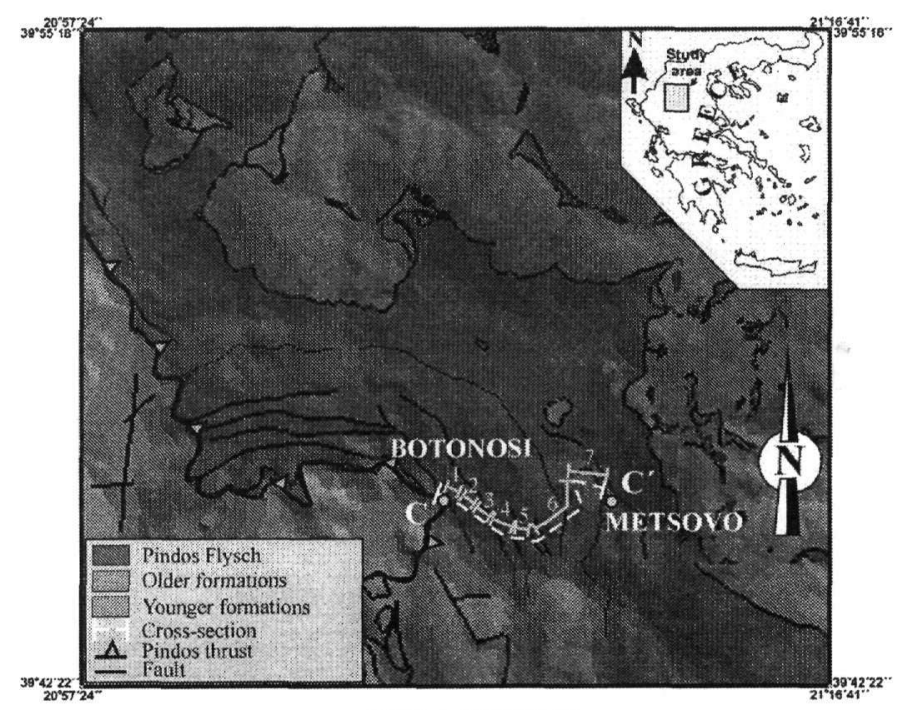

Sequence ?
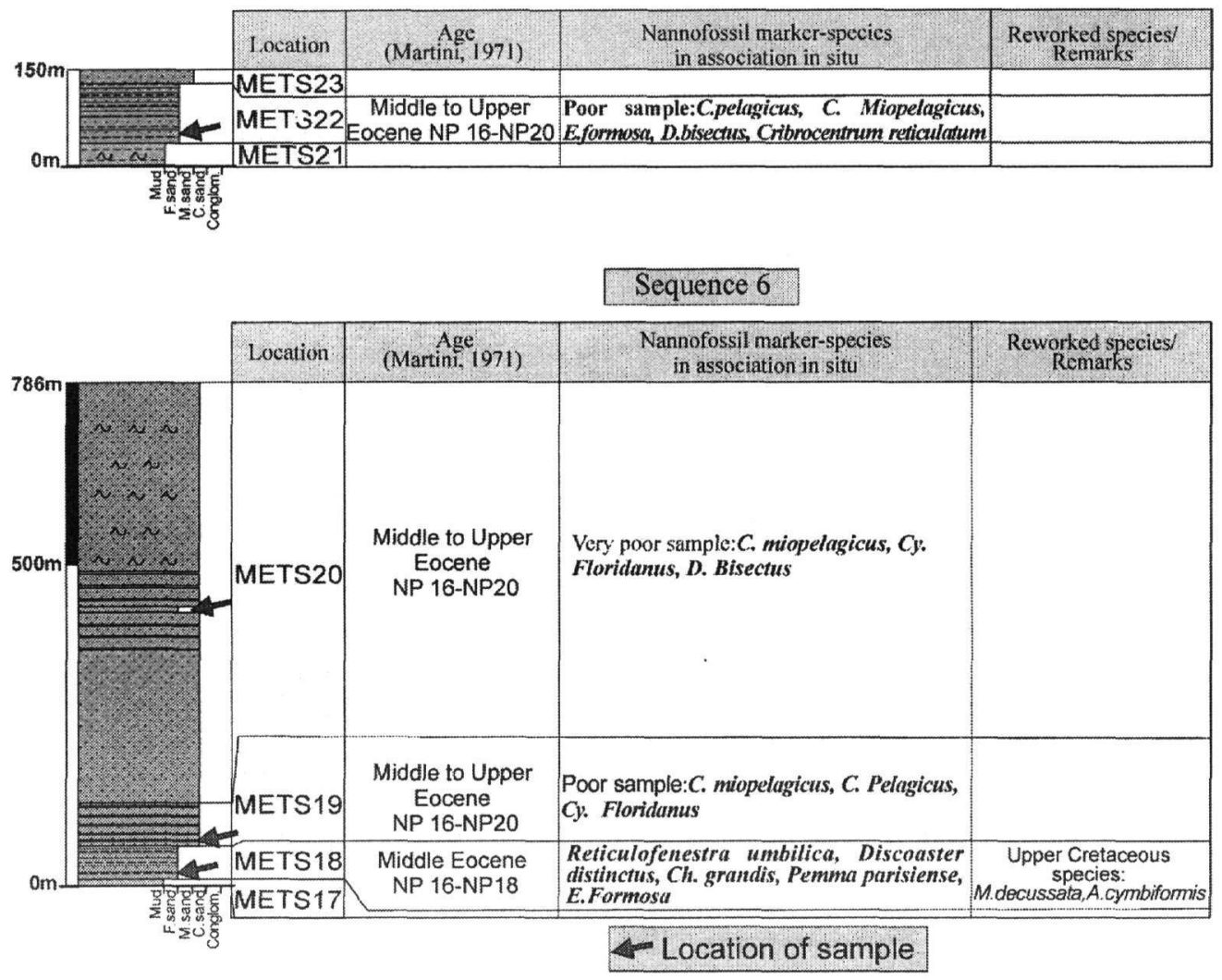

Continued 


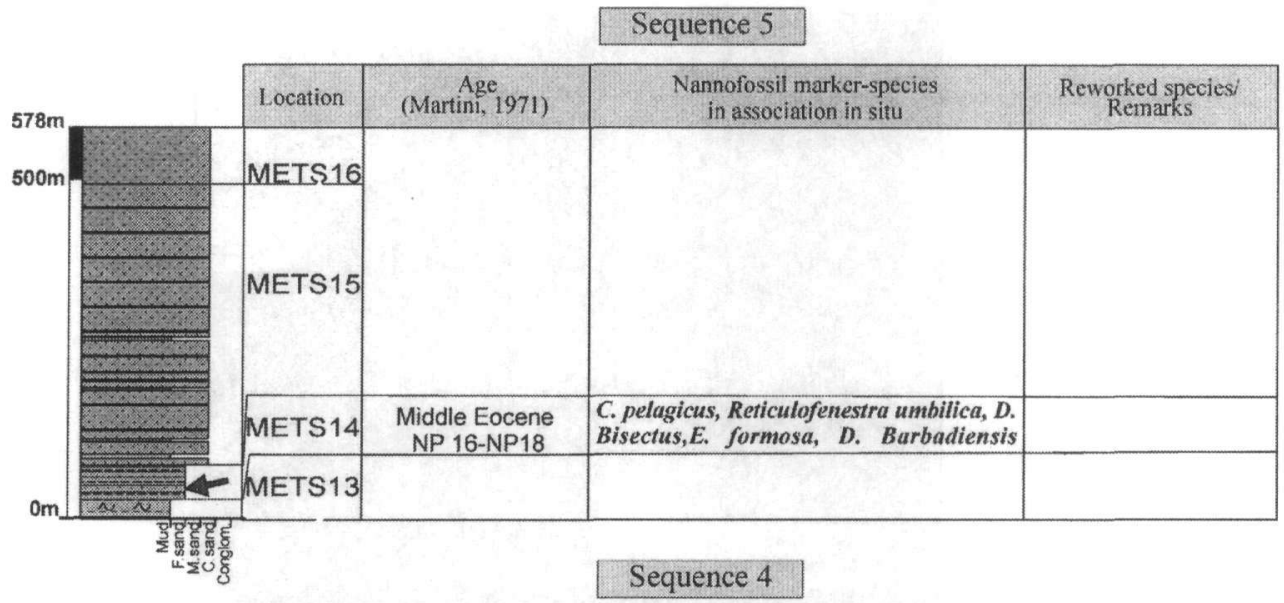

\begin{tabular}{|c|c|c|c|c|}
\cline { 2 - 4 } & Location & $\begin{array}{c}\text { Agc } \\
\text { (Martini, 1971) }\end{array}$ & $\begin{array}{c}\text { Nannofossil marker-species } \\
\text { in association in situ }\end{array}$ & $\begin{array}{c}\text { Reworked speciesi } \\
\text { Remarks }\end{array}$ \\
\hline
\end{tabular}

Sequence 3

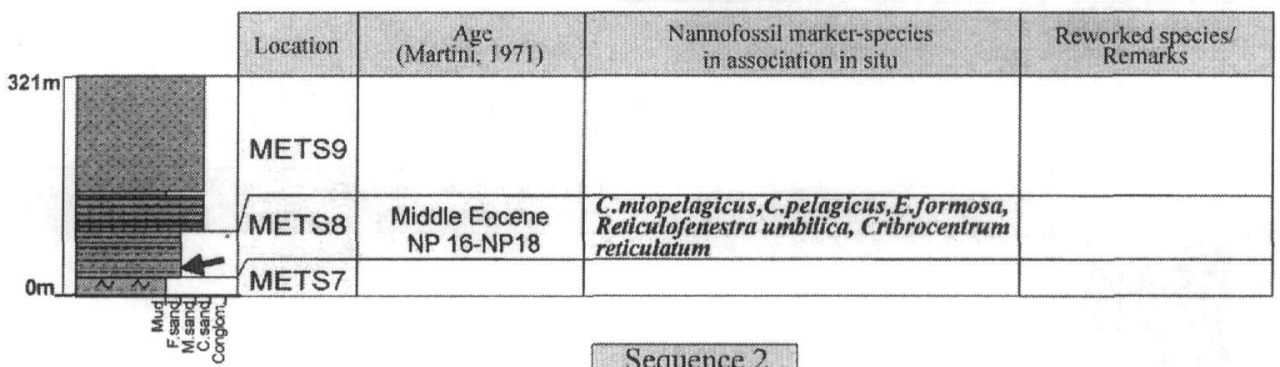

Sequence 2

\begin{tabular}{|c|c|c|c|}
\hline & $\begin{array}{c}\text { Location } \\
\text { (Martin, 1971) }\end{array}$ & $\begin{array}{c}\text { Nannofossil marker-species } \\
\text { in association in situ }\end{array}$ & $\begin{array}{c}\text { Reworked species/ } \\
\text { Remarks }\end{array}$ \\
\cline { 2 - 4 } & & EETS6 \\
\hline
\end{tabular}

\section{Sequence 1}

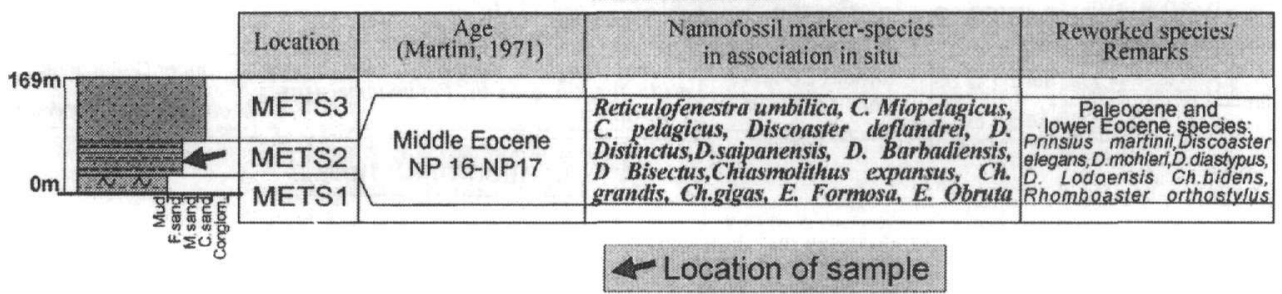

Figure 3. Cross-section C-C' broken into seven sequences. For understanding segmentation see also figure 1. 


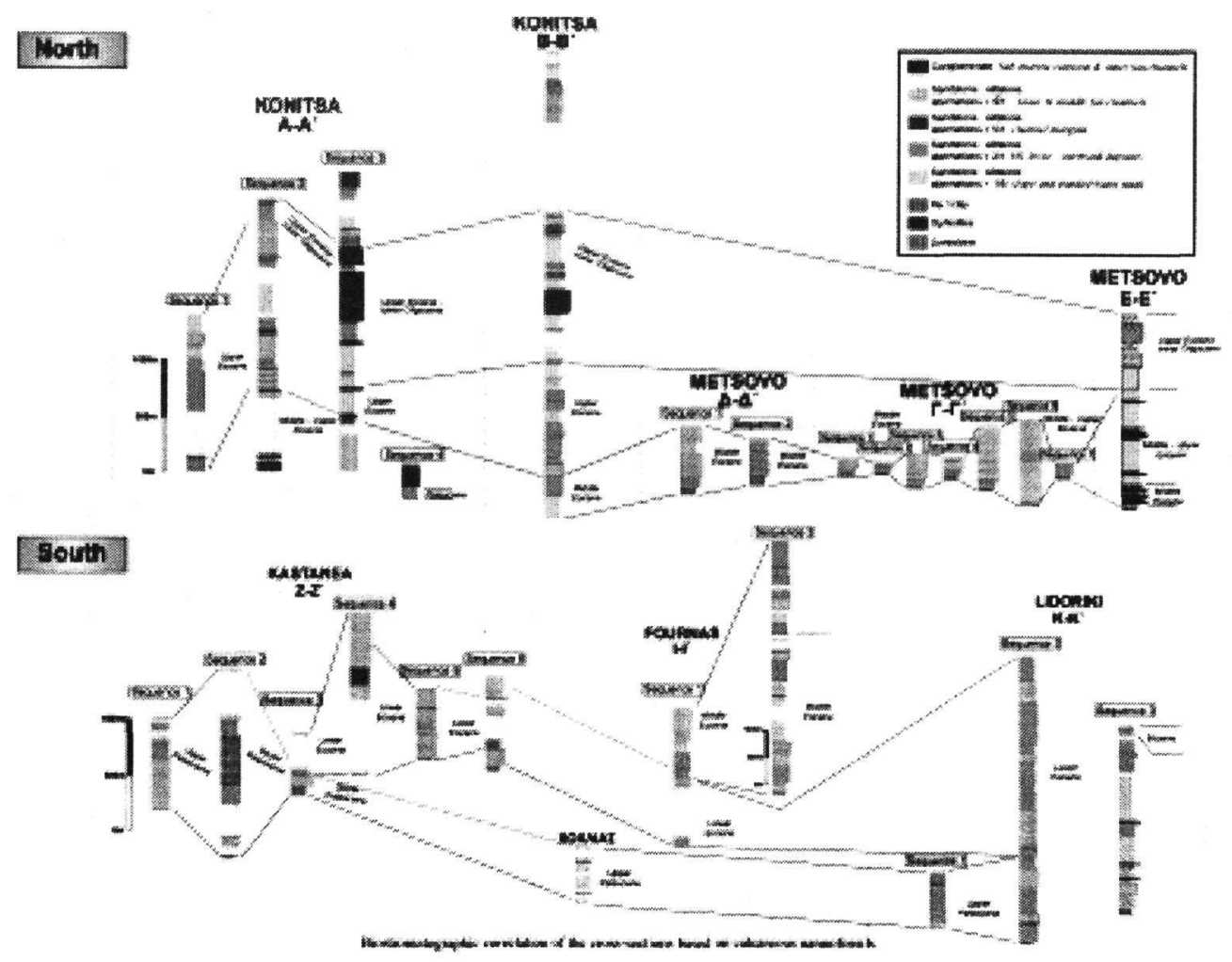

Figure 4. Biostratigraphic correlation of the studied cross-sections based on calcareous nannofossils.

\section{PALEOGEOGRAPHIC EVOLUTION - CONCLUSIONS}

In the southern part, the age of the studied clastic sediments ranges from Paleocene to middle Eocene with continual transition from west to east. On the other hand, the age of the studied sediments in the northern part ranges from middle Eocene to Late Eocene - Early Oligocene boundary, with the exception of Paleocene sediments that found in the eastern part of cross-section A-A' (Konitsa area, northern part).

Characteristic calcareous nannofossils that found and indicated the above suggested ages are for the northern part: Upper Paleocene: Prinsius bisulcu (NP5-8), Fasciculithus tympaniformis (NP7-8), Cruciplacolithus tenuis, Heliolithus kleinpellii and Sphenolithus anarrhopus (NP8-9). Eocene: Toweius gammation and Sphenolithus editus (NP12-14), Chiasmolithus grandis and Ericsonia formosa (NP16-17), Cribrocentrum reticulatum and Reticulofenestra umbilica (NP16-18).

For the southern part: Lower Palaeocene: Cruciplacolithus frequens (NP2-7). Upper Palaeocene: Fasciculithus billii (NP5), Toweius eminens, Heliolithus kleinpellii, and Fasciculithus tonii (NP8-9). Eocene: Chiasmolithus consuetus, Reticulofenestra dictyoda, and Helicosphaera seminulum (NP12-16), Geminilithella rotula, Sphenolithus compactus, and Helicosphaera bramlettei (NP1617).

According to these observations, a different basin evolution is suggested between the northern and southern parts of the basin (Fig. 5). It seems that Kastaniotikos and Sperchios faults affected the basin topography creating ridges and troughs, producing a deeper basin in the Northern part, which is suggested by the continuity of the sedimentation in this part until Oligocene. This continuation of the clastic sedimentation resulted in the complete covering of the underlying limestone, so that there are no surface exposures. On the other hand, in the southern part, sedimentation of flysch was complete by middle Eocene, and large areas of limestone exposures remain uncovered 
or covered by thin flysch deposits, creating the characteristic nappe structure due to the compressional events at the end of Eocene.

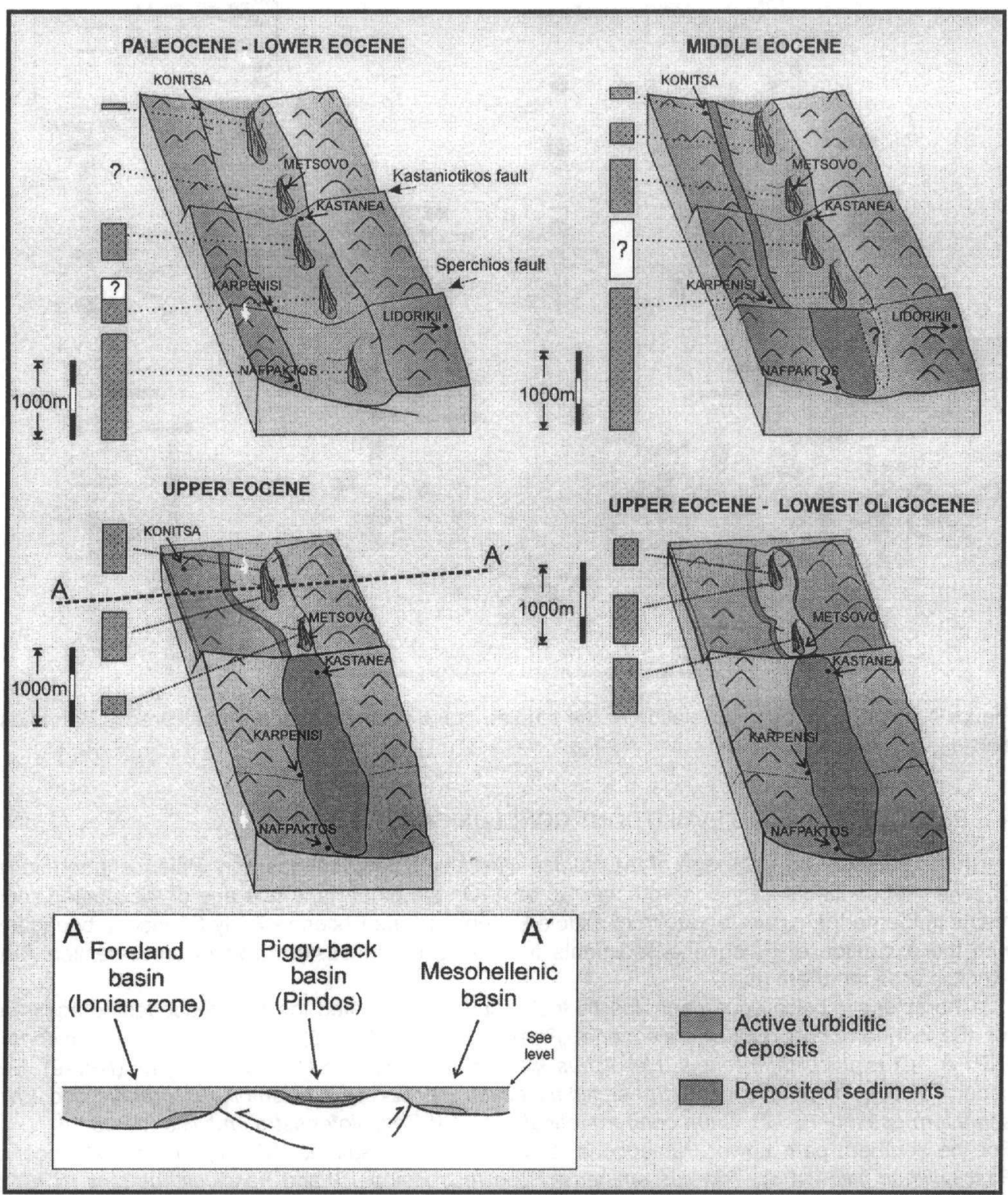

Figure 5. Block diagrams showing the palaeogeographic evolution of the Pindos zone from Palaeocene to Oligocene.

So, sedimentation in the southern part, lasted until the middle Eocene, it was followed by subaerial exposure and the migration of clastic sedimentation to the western part of Pindos zones (Pindos foreland basin of Ionian zone). At this time, in the northern part, a small restricted basin was continuously active as a piggy-back basin from upper Eocene to lower Oligocene and shallow deposits (slope and submarine canyon deposits, delta fan deposits) accumulated. 
Moreover, the suggested ages indicate an earlier closure of the basin in the area of NafpaktosLidoriki than the rest, which closed during late Eocene. This could be related to the activity of the Sperchios transfer fault, producing an additional restricted basin.

The above suggest that there were two major transfer faults, which influenced the lateral evolution of the studied basin.

\section{REFERENCES}

Fleury, J.J., 1980. Evolution d'une platforme et d'un basin dans leur cadre alpin: les zones de GavrovoTripolitze et du Pinde-Olonos. Soc.Géol. Nord, Spec. Publ. 4, 651.

Martini, I.P., Sagri, M., and Doveton, J.H., and Doveton, J.H., 1978. Lithologic transition and bed thickness periodicities in turbidite successions of the Antola Formation, northern Apennines, Italy: Sedimentation, 25, 605623.

Robertson, A.H.F., Clift, P.D., Degnan, P.J., and Jones, G., 1991. Palaeogeographic and palaeotectonic evolution of the Eastern M coditerranean Neotethys. Palaeogeography, Palaeoclimatology, Palaeoecology, 87, 289-343. 